\title{
Evaluation of Epworth Sleepiness Scale in Patients with Bronchial Hyperreactivity without Airway Obstruction
}

\author{
Havayolu Obstrüksiyonu Olmayan Ancak Bronşhiperreaktivitesi Olan \\ Hastalarda Epworth Uykululuk Skalasının Değerlendirilmesi
}

\section{Fatma Merve Tepetam}

University of Health Sciences Süreyyapasa Chest Diseases and Thoracic Surgery Training and Research Hospital, Department of Immunology and Allergy, Istanbul, Turkey

\begin{abstract}
Objective: Obstructive sleep apnea syndrome (OSAS) has been shown to be associated with inflammation of both the upper and lower respiratory tracts which were indicative for bronchial hyperresponsiveness (BHR). We aimed to investigate the sleep complaints as a manifestation of OSAS in patients who were tested for BHR with metacolin in our immunology and allergy clinic.
\end{abstract}

Materials and Methods: A retrospective cross sectional study was performed. Recorded data consisted of patients who were tested for metacolin BHR evaluation of asthma without airway obstruction (include occupational), chronic cough etiology and allergic rhinitis before planned subcutan immunotherapy. The patients were questioned with telephonically about daytime sleepiness, sleep disruption, snoring, choking and apnea using Epworth Sleepiness Scale (ESS).

Results: Of the 250 recorded patients 181 patients were contacted. 73 male and 108 female patients were included in the study. The mean age was $37.8 \pm 12.4$ years, BMI was 26.9 $\pm 5.1 \mathrm{~kg} / \mathrm{m} 2$, the mean ESS scores were $3.92 \pm 3.9$, BHR was positive in $59(32.6 \%)$ patients. Shortness of breath and chronic cough were significantly higher in BHR positive patients but ESS score was not significantly higher. While $15.3 \%$ of the BHR positive patients have excessive daytime sleepiness (ESS $>10$ ), it was only $6.6 \%$ in the BHR negative patients $(\mathrm{P}=0.06)$.

Conclusion: The patients with BHR that have not yet developed airway obstruction with high score of ESS, endication of polysomnography circle can be narrowed, the waiting period for the test can be shortened and the spread of the disease can be prevented.

Key Words: Bronchial hyperreactivity, sleepiness, Obstructive sleep apnea syndrome (OSAS)

\section{Introduction}

Methacholine challenge testing (MCT) is a method of assessing airway responsiveness. MCT is often

\section{ÖZET}

Amaç: Obstrüktif uyku apne sendromunun (OSAS), bronş hiperreaktivitesinin (BHR) göstergesi olan üst ve alt hava yolu inflamasyonu ile ilişkili olduğu gösterilmiştir. Çalışmamızda immunoloji ve alerji kliniğimize metakolin ile BHR testi yapılan hastalarda OSAS'ın göstergesi olan uyku ile ilişkili şikayetleri araştırmayı amaçladık.

Gereç ve Yöntem: Çalışmamız retrospektif kesitlel bir çalışmadır. Kaydedilen data havayolu obstruksiyonu olmayan astım düşünülen (mesleksel astım dahil), kronik öksürük nedenininin saptanması ve allerjikrinit olan hastalarda subkutan immunoterapi öncesi BHR'sinin değerlendirilmesi gibi nedenlerle metakolin ile bronkoprovakasyon testi yapılan hastalardan oluşuyordu. Hastalar Epworth Uykululuk Skalası (ESS) ile gündüz uykululuk, horlama, uyanma, boğulma hissi ve apne açisindan telefonla sorguland1.

Bulgular: Kayitlı 250 hastadan 181 hastaya telefonla ulaşılabildi. Çalışma 73'ü erkek 108'i kadın olmak üzere 181 hastadan oluşuyordu. Yaş ortalaması 37,8 $\pm 12,4$ (1366) y1l, BMI $26,9 \pm 5.1 \mathrm{~kg} / \mathrm{m} 2$, ESS skoru $3,92 \pm 3,9$ idi ve BHR $59(\% 32,6)$ hastada pozitifti. Nefes darlığ ve kronik öksürük BHR pozitif olan hastalarda anlamlı olarak yüksek bulundu fakat ESS skoru anlamlı olarak yüksek değildi. BHR pozitif olan hastalarda aşırı gündüz uykululuk (ESS $>10)$ sıklığ $1 \% 15$ iken, BHR negative olan hastalarda \%6,6 bulundu ( $\mathrm{P}=0.06)$.

Sonuç: Havayolu obstruksiyonu henüz gelişmemiş BHR'si olan ve ESS skoru yüksek olan hastalarda polisomnografi endikasyon çemberi daraltılıp test için bekleme periyodu k1saltılabilir ve hastalik tablosunun oturmasi önlenebilir.

Key Words: Bronşial hiperreaktivite, Obstrüktif uyku apne sendromu (OSAS), uykululuk

considered when patients have asthma symptoms but have not variable airway obstruction measured with post bronchodilator test, 4 weeks after antiinflammatory treatment, PEF variability or the

*Sorumlu Yazar: Dr. Fatma Merve Tepetam, University of Health Sciences Süreyyapaşa Chest Diseases and Thoracic Surgery Training and Research Hospital Departmant of Immunology and Allergy, Başıüyük mah. Maltepe Istanbul, Turkey, Tel: + 90 (506) 50487 46, Fax:+ 90 (216) 42141 50, E-mail: fatmamervealan@hotmail.com

Geliş Tarihi: 11.09.2017, Kabul Tarihi: 19.09.2017 
difference of spirometric measurments between visits. It is also a valuable tool in the evaluation of occupational asthma to distinguish cough variant asthma from other chronic cough etiologies. Most of the asthmatic patients have bronchial hyperresponsiveness (BHR) $(1,2)$. However, BHR is also seen in a wide variety of other diseases, including allergic rhinitis, chronic airway obstruction (COPD), smoking history, bronchitis and bronchiectasis. $(3,4)$.

Obstructive sleep apnea syndrome (OSAS) is characterized by reduction of dilator muscles function during sleep, which causes sleep disruption, snoring, choking, frequent awakenings, insomnia, poor sleep and daytime sleepiness. Several studies have confirmed that patients with asthma, allergic rhinitis, COPD, HT, DM and high BMI are more prone to develop OSAS (5-8). OSAS has been shown to be associated with inflammation of both the upper and lower respiratory airways (9). It is also well documented that inflammation of the airways can affect the bronchial hyperreactivity (10). BHR was found in patients with OSAS at the rate of $22 \%$ and $25 \%$ in the studies of Köktürk and Lin respectively on the other hand there were no correlation between BHR and disease severity in the same studies $(11,12)$. OSAS and inflamatory airway diseases such as allergic rhinitis, asthma, COPD can share a common cause of predisposing factors, they can be independent forms or they can be comorbidities worsening the clinical condition with common inflammatory process.

We aimed to investigate the sleep complaints as a manifestation of OSAS in patients who were applied to our immunology and allergy clinic for metacolin BHR testing with no airway obstruction, to evaluate asthma (including occupational), chronic cough etiology and airway responsiveness in patients with allergic rhinitis before planned subcutan immunotherapy (SCIT).

\section{Materials and Methods}

Study Design: A retrospective cross sectional study was performed in Sureyyapaşa Thorax and Thorax Surgery Training and Research Hospital's Department of Immunology and Allergy. The study was approved by our Hospital Committee.

We aimed to reach 250 patients without airway obstruction (FEV1/FVC>080) who had been perfomed metacolin BHR test because of asthma symptoms such as episodic breathlessness, wheezing, cough, chest tightness without variable airway obstruction, chronic non productive cough persisting for longer than eight weeks, allergic rhinitis thought to start SCIT and evaluation of occupational asthma in our immunology and allergy department. The test results were recorded together with skin prick test results, demographic data, smoking history, respiratory semptoms, body mass index (BMI) $(\mathrm{kg} / \mathrm{m} 2)$ and comorbidities as diabetes mellitus (DM), hypertension (HT). The patients were questioned with telephonically about daytime sleepiness, sleep disruption, snoring, choking and apnea using Epworth Sleepiness Scale (ESS).

Bronchoprovocation test: The 5-breath dosimeter method (Koko dosimeter, nSpire Health, Longmont, Colorado) was used according to guidelines from the American Thoracic Society. The test included 5 steps respectively: diluent only, $0.0625,0.25,1.0,4.0$ and $16.0 \mathrm{mg} / \mathrm{ml}$. Inhalation was stopped when FEV1 decreased by $20 \%$ from its baseline value. If the cumulative dose causing a $20 \%$ decrease in FEV1 (PD20 [provocative dose] methacholine) was <16 $\mathrm{mg} / \mathrm{ml}$, the methacholine challenge test was diagnosed to be positive or have BHR. All foods and drugs which can affect the test results were discontinued before the test (13).

Epworth Sleepiness Scale (ESS): The ESS is basic, eight item self-administered scale which is widely used in clinical practice to quantify the level of daytime sleepiness. The total score range is $0-24$ and excessive daytime sleepiness is considered when score is more than 10 (14).

Statistical Analysis: Results are expressed as mean \pm standard deviation (SD). Significance of difference between presence of BHR and ESS score, age and BMI were investigated with "Mann Whitney U test", for categorical parameters "Chisquare test" were used. The relation between PD 20 with ESS score and BMI were investigated with "pearson correlation test" in patients with BHR. The statistical analysis were performed using the SPSS program (SPSS Inc., IL, USA) and $\mathrm{p}$ values were analyzed using two tailed; statistical significance was considered if $p$ values were less than 0.05 .

\section{Results}

The recorded data include 250 patients who were tested for BHR. Of the 250 patients 181 patients were reached and were asked about their sleep symptoms over the telephone. 73 male and 108 female patients were included in the study. The mean age was $37.8 \pm 12.4$ (13-66) years BMI was $26.9 \pm 5.1 \mathrm{~kg} / \mathrm{m} 2$, ESS scores were $3.92 \pm 3.9$, BHR was showed in $59(32.6 \%)$ patients. Causes of testing BHR, and demographic characteristics 
of patients were given in table 1. The comorbidities like DM, HT and BMI were similar in ESS $>10$ and $<10$ patients; but there were significant positive correlations between ESS score and BMI ( $r=0.13, p=0.03)$. Among respiratory symptoms; shortness of breath and chronic cough were significantly higher in BHR positive patients; sleep symptoms including ESS score were not significantly higher in the BHR positive patients. While $15.3 \%$ of BHR positive patients have excessive daytime sleepiness (ESS $>10$ ), only $6.6 \%$ of BHR negative patients have. $(\mathrm{P}=0.06)$ (Table 2). There were no significant correlations between PD 20 values and BMI and ESS score in the patients with BHR according to Pearson correlation analyses (Table 3).

Table 1. Demographic characteristics of patients

\begin{tabular}{lc}
\hline Variables & $\begin{array}{c}\text { Patients tested } \\
\mathrm{n}=181(\%)\end{array}$ \\
\hline Age;years $\pm \mathrm{SD}$ & $37.8 \pm 12.4$ \\
Sex; Male/Female & $73 / 108$ \\
$\mathrm{BMI} ; \mathrm{kg} / \mathrm{m} 2 \pm \mathrm{SD}$ & $26.9 \pm 5.1$ \\
$\mathrm{ESS} \pm \mathrm{SD}$ & $3.92 \pm 3.9$ \\
BHR $(+)$ & $59(32.6 \%)$ \\
Smoking history & $37(20 \%)$ \\
Shortness of breath & $91(50.3 \%)$ \\
Wheezing & $40(22.1 \%)$ \\
Chronic cough & $63(34.8 \%)$ \\
Allergic Rhinitis & $48(26 \%)$ \\
HT & $6(3.3 \%)$ \\
DM & $9(5 \%)$ \\
\hline
\end{tabular}

Abbreviations: BHR: Bronchial hyperresponsiveness, BMI: Body mass index, ESS: Epworth Sleepiness Scale, DM: Diabetes mellitus, HT: Hypertension.

Table 2. Comparison between patients with BHR and patients without BHR.

\begin{tabular}{lccc}
\hline & \multicolumn{1}{c}{ BHR } & \\
\hline & Positive $(\mathrm{n}=59)$ & Negative $(\mathrm{n}=122)$ & $\mathrm{p}$ \\
\hline Age & $36.5 \pm 12.9$ & $38 \pm 12.9$ & 0.49 \\
Sex $(\mathrm{M} / \mathrm{F})$ & $38 / 21$ & $70 / 52$ & 0.42 \\
BMI & $26.5 \pm 4.8$ & $27.1 \pm 5.3$ & 0.6 \\
Smoking History & $12(20.3 \%)$ & $25(20.5 \%)$ & 1 \\
Shortness Of Breath & $37(62.7 \%)$ & $54(44.3 \%)$ & $0.02^{*}$ \\
Allergic Rhinitis & $17(28.8 \%)$ & $31(25.4 \%)$ & 0.72 \\
Chronic Cough & $27(45.8 \%)$ & $36(29.5 \%)$ & $0.045^{*}$ \\
ESS (Mean \pm SD) & $4.5 \pm 5.2$ & $3.6 \pm 3.2$ & 0.74 \\
ESS $>10(\mathrm{n})$ & $9(15.3 \%)$ & $8(6.6 \%)$ & 0.06 \\
\hline
\end{tabular}

Abbreviations: BHR: Bronchial hyperresponsiveness, BMI: Body mass index, ESS: Epworth Sleepiness Scale. ${ }^{*}$ Statistical significance $\mathrm{p}<0.05$.

Table 3. Correlation between PD 20 value and BMI, ESS score in patients with BHR.

\begin{tabular}{lcc}
\hline & \multicolumn{2}{c}{ PD20 value $\mathrm{n}=59$} \\
\hline & r value & $\mathrm{p}$ value \\
\hline ESS & -0.17 & 0.096 \\
BMI & -0.06 & 0.31
\end{tabular}

Abbreviations: BHR: Bronchial hyperresponsiveness, BMI: Body mass index, ESS: Epworth Sleepiness Scale.

\section{Discussion}

In the present study, shortness of breath and chronic cough were significantly higher in BHR positive patients, the percentage of patients with ESS $(>10)$ was higher too but was not statistically significant. The severity of BHR was not correlated with BMI and ESS score according to Pearson correlation analyses. But to the extended 
that rather than BMI, ESS score was more correlated with PD20 value. When we compare with and without excessive daytime sleepiness groups, there were no statistical significant viewpoint of BMI, HT and DM, but there is high correlation between ESS score and BMI.

In literature it was demonstrated that $25 \%$ of OSAS patients have BHR used maximum metacholin dose at $25 \mathrm{mg}$, they established $25 \%$ BHR in patients with OSAS (11). In a large cohort study of OSAS patients, $\% 4$ of OSAS patients has BHR to cold air (15). In another study which was conducted in Turkey, BHR was established at the rate of $44 \%$ with histamin (maximum $16 \mathrm{mg}$ ), the presence and severity of BHR (PD20) were correlated with severity of sleep apnea (AHI) and BMI (16). But some studies did not found relation between severity of OSAS and BHR $(11,17)$. Devoassoux et al. (18) found that continuous positive airway pressure (CPAP) can increase the BHR and they showed that at beginning BHR was $11 \%$, at the first week of treatment $40 \%$ and at fourth week $33 \%$.

The difference of our study from other studies is that; we aimed to determine if there is any difference and correlation between patients who have not just had airway obstruction but had BHR which is related airway inflammation and patients who were not yet diagnosed as OSAS but the sleep symptoms mainly ESS were begun. Although not meaningful, in patients with BHR the percentage of patients with $10<$ ESS were more than two times of patients without BHR; it may be due to airway obstruction which has not yet begun and not yet to be confirmed recognition of OSAS. We aimed in the following times to conduct polysomnography to the patients with detected risk factors and examine changings of BHR after CPAP treatment.

BHR can be a risk factor for OSAS, large scale studies are needed to determine the risk factor. The patients who have excessive daytime sleepiness and have BHR although does not have airway obstruction can be followed up closely and so endication of polysomnography circle can be narrowed, the waiting period for the test can be shortened and the spread of the disease can be prevented with pharmacological and non pharmacological approaches.

\section{References}

1. Fish JE. Bronchial challenge testing. In Middleton E, editor. Allergy: Principles and
Practice, 4th ed. St. Louis: Mosby-Year Book; 1993.p.10.

2. Tepetam FM, Duman D, Kocak N, Balikci A, Salturk C, et al. The Prevalence of $\beta 2$ Agonist Response in Patients with Non-asthmatic Eosinophilic Bronchitis (NAEB) and Spirometric Differences among Eosinophilic Airway Disorders Associated with Corticosteroid Responsive Chronic Cough. DOI: 10.7727/wimj.2017.039

3. Ramsdell JW, Nachtwey FJ, Moser KM. Bronchial hyperreactivity in chronic obstructive bronchitis. Am Rev Respir Dis 1982; 126(5): 82932.

4. Yan K, Salome CM, Woolcock AJ. Prevalence and nature of bronchial hyperresponsiveness in subjects with chronic obstructive pulmonary disease. Am Rev Respir Dis 1985; 132(1): 25-29.

5. Nieto FJ, Young TB, Lind BK, Shahar E, Samet JM, Redline S, et al. Association of sleepdisordered breathing, sleep apnea, and hypertension in a large community-based study. Sleep Heart Health Study. JAMA 2000; 283(14): 1829-1836.

6. Ballard RD, Irvin CG, Martin RJ, Pak J, Pandey $\mathrm{R}$, White DP. Influence of sleep on lung volume in asthmatic patients and normal subjects. J Appl Physiol (1985) 1990; 68(5): 2034-2041.

7. Léger D, Annesi-Maesano I, Carat F, Rugina M, Chanal I, Pribil C, et al. Allergic rhinitis and its consequences on quality of sleep: An unexplored area. Arch Intern Med 2006; 166 (16): 1744-1748.

8. Saraç S, Afş̧ar GÇ, Oruç Ö, Kırbaş G, Görgüner AM. Obstruktif Uyku Apne Sendromlu Hastalarda Ek Hastalıklar ile Obezite İlişkisi. Van Medical Journal 2015; 22(4): 246-251.

9. Olopade CO, Christon JA, Zakkar M, Hua C, Swedler WI, Schef PA, et al. Exhaled pentane and nitric oxide levels in patients with obstructive sleep apnea. Chest 1997; 111(6): 1500-1504.

10. Huang TJ, Haddad EB, Fox AJ, Salmon M, Jones C, Burgess $G$, et al. Contribution of bradykinin $\mathrm{B}(1)$ and $\mathrm{B}(2)$ receptors in allergen-induced bronchial hyperresponsiveness. Am J Respir Crit Care Med 1999; 160(5 Pt 1): 1717-1723.

11. Lin CC, Lin CY. Obstructive sleep apnea syndrome and bronchial hyperreactivity. Lung 1995; 173(2): 117-126.

12. Köktürk O, Ciftçi B. Overlap syndrome. Article in Turkish. Tuberk Toraks 2003; 51(3): 333-348.

13. Crapo RO, Casaburi R, Coates AL, Enright PL, Hankinson JL, Irvin CG et al. Guidelines for methacholine and exercise challenge testing 1999. This official statement of the American Thoracic Society was adopted by the ATS Board of Directors, July 1999. Am J Respir Crit Care Med 2000; 161(1): 309-329. 
14. Johns MW. A new method for measuring daytime sleepiness: the Epworth sleepiness scale Sleep 1991; 14(6): 540-555.

15. Thalhofer S, Dorow P, Meissner P, Luding K. Change in bronchial hyperreactivity with nCPAP respiration in patients with sleep related respiratory disorders. Pneumologie 1997; 51(3): 767-769.

16. Bulcun E, Ekici M, Ekici A, Tireli G, Karakoç T, Şentürk E, et al. Bronchial hyperresponsiveness in patients with obstructive sleep apnea syndrome. Tuberk Toraks 2013; 61(3): 221-226.
17. Köktürk O, Fırat H. Bronchial hyperreactivity in patients with obstructive sleep apnea syndrome. Diagnosis and treatment of sleep breathing disorders. Alpes Congres, Grenoble, Fransa 1998; 67 (p-69).

18. Devouassoux G, Lévy P, Rossini E, Pin I, FiorGozlan M, Henry M, et al. Sleep apnea is associated with bronchial inflammation and continuous positive airway pressure-induced airway hyperresponsiveness. J Allergy Clin Immunol 2007; 119 (3): 597-603. 